\title{
Effects of MgO Particle Loading on Gas Permeation Properties of Epoxidized Natural Rubber (ENR) / Polyvinyl Chloride (PVC) Membrane
}

(Kesan Penambahan Partikel MgO ke atas Ketelapan Gas bagi Membran Getah Asli Terepoksida (ENR) / Polivinil Klorida (PVC))

\author{
FARHAN MOHD NOR \& RIZAFIZAH OTHAMAN*
}

\begin{abstract}
A composite membrane was prepared by mixing epoxidized natural rubber (ENR) and polyvinyl chloride (PVC). An inorganic filler, $\mathrm{MgO}$, was introduced into the polymer matrix by certain percentages to form a mixed matrix membrane (MMM). The resulting membranes were characterized using FTIR, TGA, SEM and gas permeability test. FTIR results showed the incorporation of $\mathrm{MgO}$ inside the membrane matrix with the appearance of an absorption peak at $3700 \mathrm{~cm}^{-1}$ which represents the formation of $\mathrm{Mg}(\mathrm{OH})_{2}$. Thermogram from TGA analysis showed two degradation stages at $250-350^{\circ} \mathrm{C}$ and $370-500^{\circ} \mathrm{C}$, which correspond to the decomposition of PVC and ENR and the residue of fillers at $600^{\circ} \mathrm{C}$. SEM images of the membranes showed that pores were developed as fillers were introduced to the membrane. The size of the pores also increased with the increase of filler percentage. As for gas permeation test, the permeability values of $\mathrm{CO}_{2}$ and $\mathrm{N}_{2}$ for ENR/PVC membrane were the lowest. The permeability values increased with the addition of $\mathrm{MgO}$ to the membrane. The permeability of $\mathrm{CO}_{2}$ was also the highest for all membranes.
\end{abstract}

Keywords: ENR-50; gas separation; inorganic filler; polyvinyl chloride

\section{ABSTRAK}

Membran komposit telah disediakan dengan mencampurkan getah asli terepoksida (ENR) dengan polivinil klorida $(P V C)$. Pengisi tak organik $(\mathrm{MgO})$ telah dimasukkan ke dalam matriks polimer tersebut dengan peratusan tertentu untuk menghasilkan membran campuran matriks (MMM). Membran yang terhasil telah dicirikan dengan menggunakan FTIR, TGA, SEM dan ujian ketelapan gas. Keputusan ujian FTIR telah menunjukkan kehadiran MgO di dalam matriks membran apabila terdapat puncak serapan pada $3700 \mathrm{~cm}^{-1}$ yang mewakili pembentukan $\mathrm{Mg}(\mathrm{OH})_{2}$. Termogram daripada analisis TGA menunjukkan dua peringkat penguraian, iaitu pada $250-350^{\circ} \mathrm{C}$ dan $370-500^{\circ} \mathrm{C}$ yang mewakili penguraian PVC dan ENR. Residu pada suhu $600^{\circ} \mathrm{C}$ pula adalah disebabkan pengisi yang tidak terurai. Mikrograf daripada ujian SEM menunjukkan kehadiran liang dengan kehadiran pengisi di dalam matriks membran. Saiz liang juga dilihat bertambah dengan penambahan peratusan pengisi. Untuk ujian ketelapan gas, nilai ketelapan gas $\mathrm{CO}_{2}$ dan $\mathrm{N}_{2}$ bagi membran ENR/ $P V C$ adalah yang terendah. Nilai ketelapan dilihat semakin meningkat dengan penambahan MgO ke dalam membran. Ketelapan gas $\mathrm{CO}_{2}$ pula adalah yang tertinggi bagi semua membran.

Kata kunci: ENR-50; pemisahan gas; pengisi tak organik; polivinil klorida

\section{INTRODUCTION}

Recently, a wide range of polymeric membranes were studied aggressively in search of gas separation process with low price, economical processability, good thermostability and high energy efficiency (Chung et al. 2007; Ge et al. 2011). The studied polymers include polyisoprene and thermoplastic polymers such as polycarbonate, polystyrene and polyvinylchloride (Chen et al. 2000; Dobre et al. 2011; Nagasaki et al. 1996; Rajabi et al. 2013). Johnson and Thomas (1999) stated that the membrane for gas separation process needs to meet several criteria which are high permeability to the desired gas, high selectivity and resistance to processing conditions. However, the drawback in gas separation membrane research is the tradeoff limitation between gas permeability and selectivity (Robeson 2008, 1991).
To overcome this problem, mixed matrix membrane (MMM), the mixture of organic polymer matrix with inorganic particles as fillers, is believed to be the alternative in optimizing permeability and selectivity of polymeric membranes. The addition of fillers also increases thermal stability, physical properties and mechanical strength of the membrane (Chung et al. 2007). Inorganic fillers also act to create preferential permeation pathways for selective permeability while posing a barrier for undesired permeation in order to improve separation performance (Jadav \& Singh 2009). Moreover, the fillers can solve the fragility inherent usually found in polymeric membranes (Goh et al. 2011). The filler used must be compatible with the membrane matrix in order to prepare a homogenous and stable MMM. Some of the inorganic particles used as fillers in MMM include silica, 
zeolites and metal oxides (Şen et al. 2007; Wahab et al. 2012; Zulfikar et al. 2007).

In this study, epoxidized natural rubber (ENR) was blended with polyvinyl chloride (PVC) to produce an elastic and strong membrane. A study by Ibrahim and Dahlan (1998) reported that PVC has good interaction with ENR. PVC is expected to provide mechanical strength to the membrane, while ENR assists the permeability and selectivity. However, ENR should be used in higher proportion in order to produce a blend that is flexible and mechanically tough to be used as a self-supporting membrane (Jon et al. 2013).

Inorganic filler used in this study is magnesium oxide $(\mathrm{MgO})$. The filler was introduced inside the polymer matrix by certain percentages by mass before the membrane was produced. The incorporation of $\mathrm{MgO}$ inside the membrane was expected to improve the gas permeability of the membrane as the percentage increased. The effect of filler addition to chemical, physical and gas permeation properties were discussed at the end of this study.

\section{EXPERIMENTAL DETAILS}

\section{MATERIALS}

ENR-50 used in this study was supplied by Malaysian Rubber Board. The PVC was supplied by Industrial Resin (M) Ltd., tetrahydrofuran (THF) by Systerm and $\mathrm{MgO}$ by Merck.

\section{ENR/PVC AND ENR/PVC/MGO MEMBRANE PREPARATION}

The preparation of ENR/PVC thermoplastic elastomer (TPE) was done by blending the PVC with epoxidized natural rubber (ENR-50) using a melt blend internal mixer at the temperature of $160^{\circ} \mathrm{C}$ for approximately $13 \mathrm{~min}$. Several ratio of ENR to PVC have been studied but the best ratio for a cured composite and flexible self-supporting membrane was 60:40 (w/w \%), which was then employed in this study. ENR/PVC matrix was dissolved in THF for $24 \mathrm{~h}$ with the ratio of 1:8 (w/v). Swollen polymer matrix was then stirred with magnetic stirrer for another $24 \mathrm{~h}$ until a homogeneous solution was obtained. In preparing the ENR/PVC membrane, the solution was casted using casting knife onto a flat glass plate. The preparation of ENR/PVC/ $\mathrm{MgO}$ membrane was done by adding $\mathrm{MgO}$ to the ENR/PVC solution with 2,5 and $8 \%$ (w/w \%). These percentages were used to study the effects of different amount of $\mathrm{MgO}$ on the properties of the membranes. $\mathrm{MgO}$ was not added more than $8 \%$ because higher loading will result in high agglomeration and the membrane become brittle. Then, $\mathrm{ENR} / \mathrm{PVC} / \mathrm{MgO}$ solution was stirred for another $24 \mathrm{~h}$ before it was casted. The thickness of the membrane was set to be approximately $0.25 \mathrm{~mm}$. The casted membrane was immersed in distilled water for solvent exchange to occur before being peeled off. The membrane prepared was then stored to dry before characterization.

\section{CHARACTERIZATION}

The membranes functional groups were determined using Perkin Elmer Fourier Transform Infrared Spectroscopy, (GX FTIR System). Thermal gravimetric analysis was carried out using a Mettler Toledo thermogravimetric analyser (TGA/SDTA 851), performed under nitrogen atmosphere over temperature range of $50-600^{\circ} \mathrm{C}$ with $20^{\circ} \mathrm{C} \cdot \mathrm{min}^{-1}$ heating rate and scanning electron microscopy was used to observe the morphology of the membranes.

\section{GAS PERMEATION TEST}

Gas permeation properties of the membranes were tested using constant pressure/variable volume technique. The gases used were purified nitrogen $\left(\mathrm{N}_{2}\right)$ and purified carbon dioxide $\left(\mathrm{CO}_{2}\right)$. The pressures used for the permeability test were 2,4 , and 6 bars at room temperature. Gas permeability was determined using (1):

$$
\mathrm{P}=\frac{q l}{\mathrm{~A}\left(p_{1}-p_{2}\right)}
$$

where $\mathrm{P}$ is the permeability expressed in Barrer (1 Barrer $\left.=10^{-10} \mathrm{~cm}^{3}(\mathrm{STP}) \mathrm{cm} / \mathrm{cm}^{2} \cdot \mathrm{s} \cdot \mathrm{cmHg}\right), q$ is the flow rate of the permeated gas passing through the membrane $\left(\mathrm{cm}^{3} / \mathrm{s}\right), l$ is membrane thickness $(\mathrm{cm}), A$ is the effective membrane area $\left(\mathrm{cm}^{2}\right)$, while $p_{1}$ and $p_{2}$ are the absolute pressure of the feed side and permeate side, respectively $(\mathrm{cmHg})$.

The selectivity coefficient, $\propto$ of the membrane was calculated from the permeability (P) obtained from (1) using (2),

$$
\propto=\frac{P_{\mathrm{CO}_{2}}}{P_{N_{2}}},
$$

where $P_{\mathrm{CO}_{2}}$ is the permeability value of $\mathrm{CO}_{2}$ and $P_{\mathrm{N}_{2}}$ is the permeability value of $\mathrm{N}_{2}$ gas.

\section{RESULTS AND DISCUSSION}

\section{FTIR ANALYSIS}

Figure 1 shows the FTIR spectrum for ENR/PVC and ENR/ $\mathrm{PVC} / \mathrm{MgO}$ membranes. Both the spectrums show similar peaks of ENR and PVC functional groups, except for the peak at $3700 \mathrm{~cm}^{-1}$ for ENR/PVC/MgO membrane, which is attributed to the presence of $\mathrm{Mg}(\mathrm{OH})_{2}$, as reported by Foster et al. (2002). This was due to the interaction of $\mathrm{MgO}$ with moisture. Apart from that distinctive peak, similar absorption peaks for both membranes were observed in the range of 3000-2800 $\mathrm{cm}^{-1}$, which corresponded to the $\mathrm{C}-\mathrm{H}$ stretching. The peak at $1450 \mathrm{~cm}^{-1}$ marks the presence of $\mathrm{C}-\mathrm{H}$ bonding while the bands at $1254 \mathrm{~cm}^{-1}$ corresponded to the $\mathrm{C}-\mathrm{O}-\mathrm{C}$ asymmetric vibration. The presence of $\mathrm{C}-\mathrm{O}-\mathrm{C}$ vibration of epoxy ring can be seen at the absorption peak of $874 \mathrm{~cm}^{-1}$, while the absorption peak of $\mathrm{C}-\mathrm{Cl}$ functional group of PVC is represented by the absorption peak $699 \mathrm{~cm}^{-1}$ (Bandyopadhyay et al. 2006). The broad peaks at $3459 \mathrm{~cm}^{-1}$ 


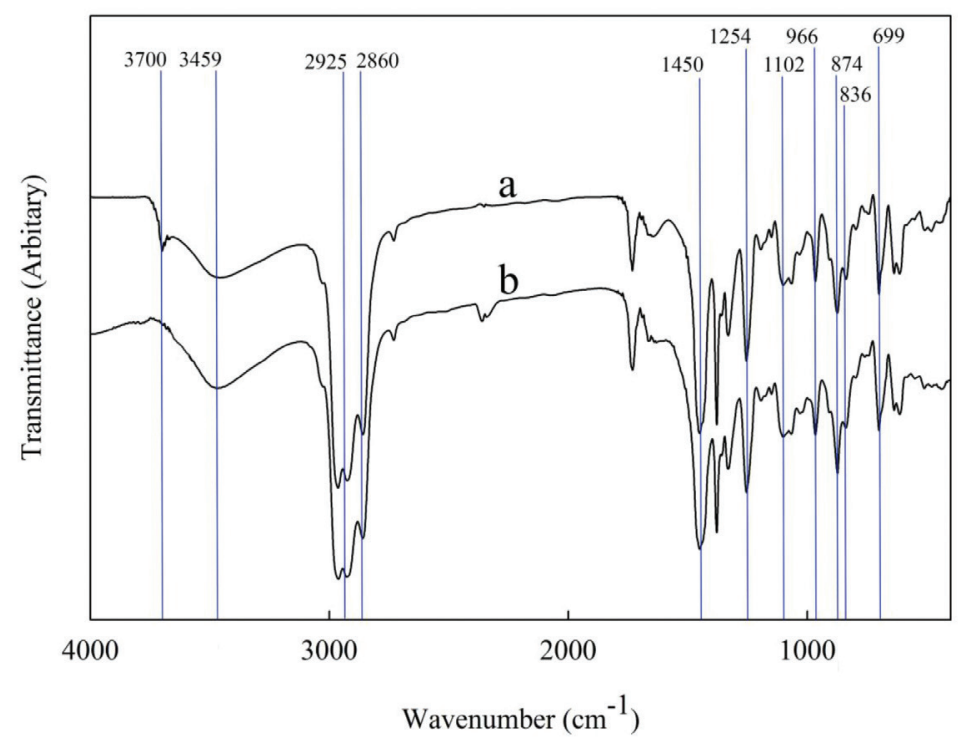

FIGURE 1. FTIR spectrum of a) ENR/PVC/MgO and b) ENR/PVC membrane

for both membranes are attributed to the presence of $\mathrm{OH}$ functional group that might result from the water used during the preparation of the membrane.

\section{THERMOGRAVIMETRIC ANALYSIS (TGA)}

Thermogravimetric analysis was done to study the decomposition of the membranes. Figure 2 shows the TGA curves of ENR/PVC and ENR/PVC/MgO membranes. Referring to the figure, two clear degradation stages can be seen. The first degradation stage of the membranes is at the temperature range of $250-350^{\circ} \mathrm{C}$. Degradation at this temperature can be assigned to the degradation of PVC matrix (Blazevska-Gilev \& Spasesk 2010). The second degradation stage occurs at the temperature range of $370-500^{\circ} \mathrm{C}$, which can be attributed to the degradation of polyisoprene chains in ENR (Hakim \& Ismail 2009).

Membrane with no filler was observed to have the lowest residual percentage at $600^{\circ} \mathrm{C}$, followed by membrane with 2, 5 and $8 \% \mathrm{MgO}$. Referring to Table 1 , the residual percentage of ENR/PVC membrane is $4.9 \%$ compared with membranes with $\mathrm{MgO}$ fillers. This was due to the amount of fillers used in those membranes. $\mathrm{MgO}$ degrades at temperature higher than $600^{\circ} \mathrm{C}$, explaining the residues left at that particular temperature. Table 1 also shows that the $\mathrm{MgO}$ residual percentages are less than the initial percentages used as fillers. This could be the result of fillers being leached out of the membranes during the phase inversion process.

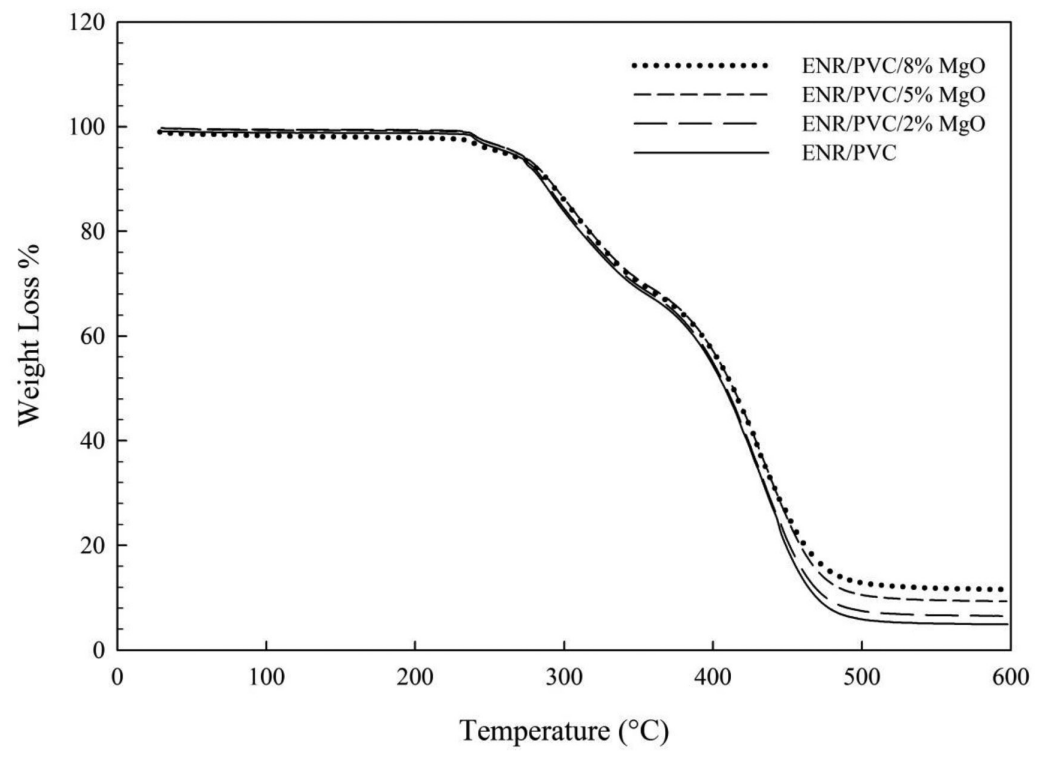

FIGURE 2. TGA curves for ENR/PVC membrane with 2, 5 and $8 \% \mathrm{MgO}$ fillers 
TABLE 1. Residual percentages of membranes and fillers

\begin{tabular}{lccc}
\hline Membrane & $\begin{array}{c}\text { Filler's initial amount } \\
(\%)\end{array}$ & $\begin{array}{c}\text { Membrane residues } \\
(\%)\end{array}$ & $\begin{array}{c}\text { Filler residues } \\
(\%)\end{array}$ \\
\hline ENR/PVC & 0 & 4.9 & 0 \\
ENR/PVC/2\% MgO & 2 & 6.5 & 1.6 \\
ENR/PVC/5\% MgO & 5 & 9.3 & 4.4 \\
ENR/PVC/8\% MgO & 8 & 11.6 & 6.7 \\
\hline
\end{tabular}
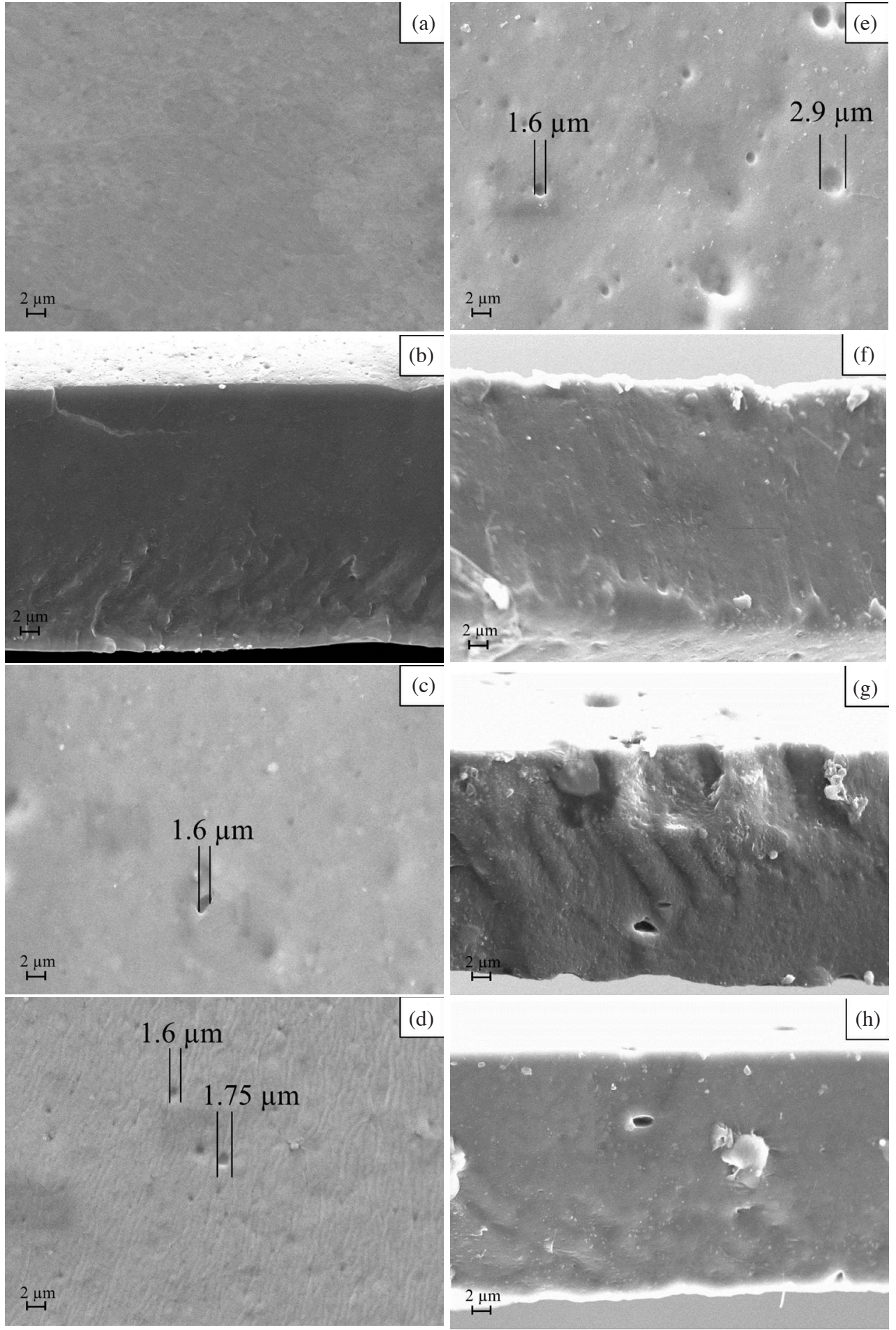

FIGURE 3. SEM images of a) ENR/PVC membrane surface, b) ENR/PVC membrane cross section, surfaces of c) ENR/PVC/2\% MgO,d) ENR/ $\mathrm{PVC} / 5 \% \mathrm{MgO}, \mathrm{e}$ ) ENR/PVC/8\% $\mathrm{MgO}$ and the cross sections of f) ENR/PVC/2\% $\mathrm{MgO}, \mathrm{g}$ ) ENR/PVC/5\% $\mathrm{MgO}$ and h) ENR/PVC/8\% MgO 


\section{MORPHOLOGY}

Morphology of the membranes prepared were studied using scanning electron microscopy (SEM). SEM images at $5000 \times$ magnification of surfaces and cross sections of the membranes are shown in Figure 3. No pores can be seen on the surface and cross section of ENR/PVC membrane. However, as fillers were added to the membranes, pores were visible on the surfaces of the membranes. From Figure 3(c), 3(d) and 3(e), more pores seemed to be developed as more fillers were introduced into the membrane. Apart from that, increments of pore sizes were also observed. ENR/PVC/2\% $\mathrm{MgO}$ membrane had pores with diameter ranging from 1.3-1.6 $\mu \mathrm{m}$. Pore diameter of ENR/PVC/5\% $\mathrm{MgO}$ membrane increased from 1.6-1.8 $\mu \mathrm{m}$, while the pore diameter of ENR/PVC/8\% MgO membrane increased from 1.4-2.9 $\mu \mathrm{m}$. The cross sections of the filled membranes (Figure 3(f), 3(g), 3(h)) also show the integration of fillers inside the membrane matrix.

The presence of pores inside the membranes was due to the substitution of the dense structure of the polymer chains by the highly porous inorganic particles. This results in pores or microvoids to be developed (Hosseini et al. 2007). As more filler were present inside the membrane, more dense structures were being substituted, resulting in the formation of more microvoids. Pores might also develop as some of the fillers were leached out of the membrane during the phase inversion process, leaving voids inside the membrane matrix (Arthanareeswaran et al. 2008; Chen et al. 2010). Apart from that, the phase inversion itself can contribute to pore formation as the solvent exchange occurs between THF and water.

\section{GAS PERMEATION PROPERTIES}

Gas permeability test was carried out to study the effect of fillers addition to the membrane. The permeability of the membranes is presented in Figure 4. The gas permeability values of ENR/PVC/MgO membranes are higher than the values of ENR/PVC membrane for both gases. The gas permeability increased with increasing amount of $\mathrm{MgO}$ added to the membrane. Carbon dioxide also exhibits higher permeability value compared to nitrogen gas for all membranes.

Several factors have been considered to have influenced the permeability results of these membranes. The first one is the presence of pores or microvoids inside the $\mathrm{MgO}$ filled membrane, resulting in higher permeability for both gases. However, since $\mathrm{CO}_{2}$ has smaller kinetic diameter (3.3 $)$ than $\mathrm{N}_{2}$ (3.64 ̊) (Khudyakov et al. 2009), $\mathrm{CO}_{2}$ diffuses faster, resulting in higher permeability values for all membranes.

The permeability of the gases also influenced the selectivity coefficient of the membranes, as presented in Table 2. The difference in the permeability of $\mathrm{CO}_{2}$ and $\mathrm{N}_{2}$ (calculated using (2)) for ENR/PVC membrane can be observed due of the high selectivity values. Unfilled membrane is non-porous and dense, making the permeation of gases through it to depend on solutiondiffusion mechanism. Thus, carbon dioxide permeates easier. However, in $\mathrm{MgO}$ filled membranes, pores were developed, resulting in high permeability and thus, low selectivity. This is consistent with the report by Scholes et al. (2008), stating that membrane with high permeability has low selectivity.

Another factor to be considered to have influenced the selectivity of the membranes is the interaction of gases with membrane matrix and filler surfaces. Matteucci et al. (2008) reported that there is interaction between $\mathrm{CO}_{2}$ and $\mathrm{MgO}$. This was due to the acidity of $\mathrm{CO}_{2}$, which results in high affinity of physisorption towards basic $\mathrm{MgO}$ and $\mathrm{Mg}(\mathrm{OH})_{2}$. The interaction results in large adsorption of

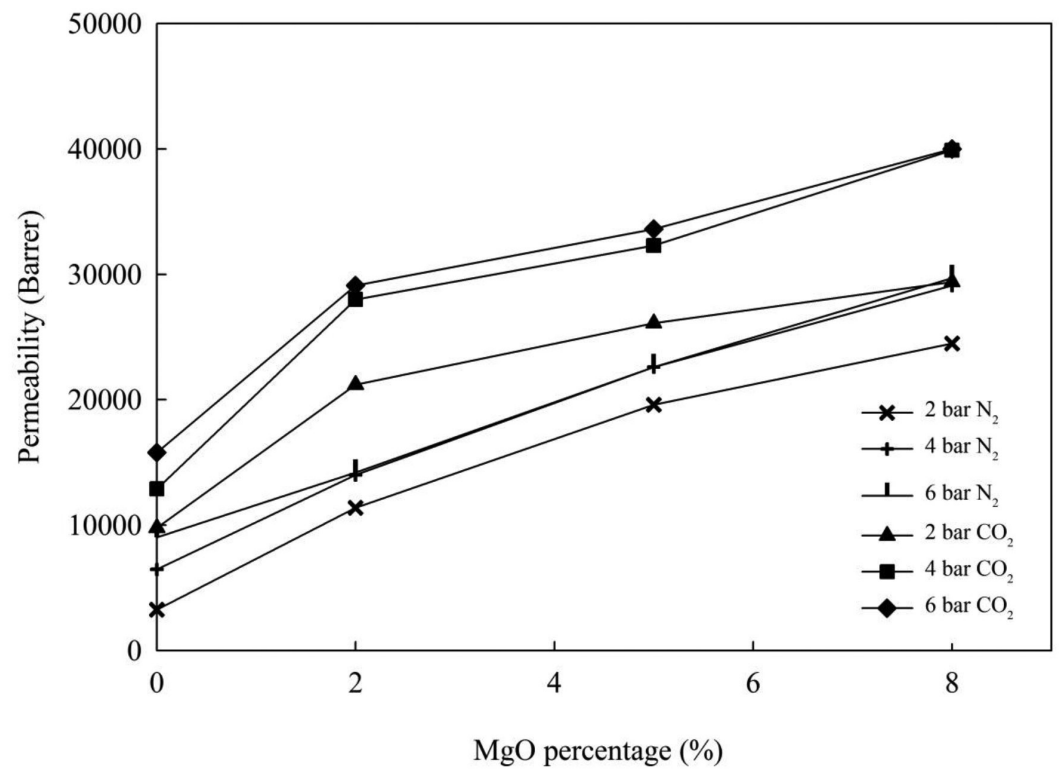

FIGURE 4.Gas permeability test result of ENR/PVC membrane and ENR/PVC/MgO membranes 
TABLE 2. Selectivity $(\propto)$ of $\mathrm{CO}_{2} / \mathrm{N}_{2}$ for ENR/PVC membrane and ENR/PVC/MgO membranes

\begin{tabular}{ccccc}
\hline Pressure (Bar) & ENR/PVC & ENR/PVC/2\% MgO & ENR/PVC/5\% MgO & ENR/PVC/8\% MgO \\
\hline 2 & 3.0 & 1.8 & 1.3 & 1.2 \\
4 & 2.0 & 2.0 & 1.4 & 1.4 \\
6 & 1.7 & 2.1 & 1.5 & 1.4 \\
\hline
\end{tabular}

$\mathrm{CO}_{2}$ even at low pressure, which consequently enhanced the gas permeability and increased its selectivity. Nitrogen, however, is an inert gas, making permeability to depend only on its kinetic size which correlates with pore size of the membrane.

\section{CONCLUSION}

The addition of $\mathrm{MgO}$ into the ENR/PVC matrix has improved pore formation inside the membrane. Membrane with higher filler percentage was observed to exhibit more pores compared to membranes with lower filler percentage. Thermal degradation showed that some filler were leached out of the membrane during preparation. Higher filler loading also influenced gas permeability of the membranes. Membrane with $8 \% \mathrm{MgO}$ was more permeable to both $\mathrm{CO}_{2}$ and $\mathrm{N}_{2}$ gases, with $\mathrm{CO}_{2}$ permeation value being the highest for all membranes due to smaller kinetic diameter and interaction of the gas with fillers.

\section{ACKNOWLEDGEMENTS}

The authors would like to acknowledge the Polymer Research Centre UKM (PORCE), School of Chemical Sciences and Food Technology, Faculty of Science and Technology, Centre for Research and Instrumentation Management (CRIM) and Fuel Cell Institute, Universiti Kebangsaan Malaysia, for providing facilities and financial support through UKM-GUP-2011-226.

\section{REFERENCES}

Arthanareeswaran, G., Sriyamuna Devi, T.K. \& Raajenthiren, M. 2008. Effect of silica particles on cellulose acetate blend ultrafiltration membranes: Part I. Separation and Purification Technology 64(1): 38-47.

Bandyopadhyay,A., Sarkar, M. \& Bhowmick,A. 2006. Structureproperty relationship in sol-gel derived polymer/silica hybrid nanocomposites prepared at various $\mathrm{pH}$. Journal of Materials Science 41(18): 5981-5993.

Blazevska-Gilev, J. \& Spasesk, D. 2010. Formal kinetic analysis of PVC thermal degradation. Journal of the University of Chemical Technology and Metallurgy 45(3): 251-254.

Chen, S.H., Huang, S.L., Yu, K.C., Lai, J.Y. \& Liang, M.T. 2000. Effect of $\mathrm{CO} 2$ treated polycarbonate membranes on gas transport and sorption properties. Journal of Membrane Science 172(1-2): 105-112.

Chen, W., Su, Y., Zhang, L., Shi, Q., Peng, J. \& Jiang, Z. 2010. In situ generated silica nanoparticles as pore-forming agent for enhanced permeability of cellulose acetate membranes. Journal of Membrane Science 348(1-2): 75-83.

Chung, T.S., Jiang, L.Y., Li, Y. \& Kulprathipanja, S. 2007. Mixed matrix membranes (MMMs) comprising organic polymers with dispersed inorganic fillers for gas separation. Progress in Polymer Science 32(4): 483-507.

Dobre, T., Pârvulescu, O.C., Sanchez-Marcano, J., Stoica, A., Stroescu, M. \& Iavorschi, G. 2011. Characterization of gas permeation through stretched polyisoprene membranes. Separation and Purification Technology 82: 202-209.

Foster, M., Furse, M. \& Passno, D. 2002. An FTIR study of water thin films on magnesium oxide. Surface Science 502503: 102-108.

Ge, L., Zhu, Z. \& Rudolph, V. 2011. Enhanced gas permeability by fabricating functionalized multi-walled carbon nanotubes and polyethersulfone nanocomposite membrane. Separation and Purification Technology 78(1): 76-82.

Goh, P.S., Ismail, A.F., Sanip, S.M., Ng, B.C. \& Aziz, M. 2011. Recent advances of inorganic fillers in mixed matrix membrane for gas separation. Separation and Purification Technology 81(3): 243-264.

Hakim, R.N. \& Ismail, H. 2009. Comparison of the effects of organoclay loading on the curing and mechanical properties of organoclay-filled epoxidised natural rubber nanocomposites and organoclay-filled natural rubber nanocomposites. Journal of Physical Science 20(2): 37-59.

Hosseini, S.S., Li, Y., Chung, T.S. \& Liu, Y. 2007. Enhanced gas separation performance of nanocomposite membranes using $\mathrm{MgO}$ nanoparticles. Journal of Membrane Science 302(1-2): 207-217.

Ibrahim, A. \& Dahlan, M. 1998. Thermoplastic natural rubber blends. Progress in Polymer Science 23(4): 665-706.

Jadav, G.L. \& Singh, P.S. 2009. Synthesis of novel silicapolyamide nanocomposite membrane with enhanced properties. Journal of Membrane Science 328(1-2): 257-267.

Johnson, T. \& Thomas, S. 1999. Nitrogen/oxygen permeability of natural rubber, epoxidised natural rubber and natural rubber/epoxidised natural rubber blends. Polymer 40(11): 3223-3228.

Jon, N., Samad, N.A., Abdullah, N.A., Abdullah, I. \& Othaman, R. 2013. Influence of silica addition on the properties of epoxidised natural rubber/polyvinyl chloride composite membrane. Journal of Applied Polymer Science 129(5): 2789-2795.

Khudyakov, I.V., Zopf, D.R. \& Turro, N.J. 2009. Polyurethane nanocomposites. Designed Monomers and Polymers 12(4): 279-290.

Matteucci, S., Raharjo, R.D., Kusuma, V.A., Swinnea, S. \& Freeman, B.D. 2008. Gas permeability, solubility, and diffusion coefficients in 1,2-Polybutadiene containing magnesium oxide. Macromolecules 41(6): 2144-2156.

Nagasaki, Y., Hashimoto, Y., Kato, M. \& Kimijima, T. 1996. Gas permeation properties of organosilicon-containing polystyrenes. Journal of Membrane Science 110(1): 91-97.

Rajabi,Z., Moghadassi, A.R., Hosseini, S.M. \& Mohammadi, M. 2013. Preparation and characterization of polyvinylchloride based mixed matrix membrane filled with multi walled carbon nano tubes for carbon dioxide separation. Journal of Industrial and Engineering Chemistry 19(1): 347-352. 
Robeson, L.M. 2008. The upper bound revisited. Journal of Membrane Science 320(1-2): 390-400.

Robeson, L.M. 1991. Correlation of separation factor versus permeability for polymeric membranes. Journal of Membrane Science 62(2): 165-185.

Scholes, C.A., Kentish, S.E. \& Stevens, G.W. 2008. Carbon dioxide separation through polymeric membrane systems for flue gas applications. Recent Patents on Chemical Engineering 1: 52-66.

Şen, D., Kalıpçılar, H. \& Yilmaz, L. 2007. Development of polycarbonate based zeolite 4A filled mixed matrix gas separation membranes. Journal of Membrane Science 303(12): $194-203$

Wahab, M.F.A., Ismail, A.F. \& Shilton, S.J. 2012. Studies on gas permeation performance of asymmetric polysulfone hollow fiber mixed matrix membranes using nanosized fumed silica as fillers. Separation and Purification Technology 86: 41-48.
Zulfikar, M.A., Mohammad, A.W., Kadhum, A.A. \& Hilal, N. 2007. Synthesis and characterization of poly(methyl methacrylate)/SiO2 hybrid membrane. Materials Science and Engineering: A 452453: 422-426.

Faculty of Science and Technology

Universiti Kebangsaan Malaysia

43600 Bangi, Selangor Darul Ehsan

Malaysia

*Corresponding author; email: rizafizah@ukm.edu.my

Received: 15 January 2014

Accepted: 15 November 2014 